\title{
The Importance of Literacy
}

\author{
Sibel Pekkolay*
}

${ }^{1}$ Kanuni Sultan Süleyman İmam Hatip Ortaokulu, Bağlar, Diyarbakır, Turkey

DOI: $10.36347 /$ sjahss.2022.v10i01.002

| Received: 03.12.2021 | Accepted: 07.01.2022 | Published: 20.01.2022

*Corresponding author: Sibel Pekkolay

Kanuni Sultan Süleyman İmam Hatip Ortaokulu, Bağlar, Diyarbakır, Turkey

Abstract

Review Article

Every society has to consist of people who show common behaviors and also engage in very different activities in order to preserve their existence. Successful individuals of the future will be individuals who can access information, use technology to reach information, solve problems and learn by themselves. Information societies now need individuals with lifelong learning skills. Being literate after the twenty-first century requires more than just knowing how to read, write, or basic mathematical knowledge. The existence of writing as a communication tool is a very important development. Every individual who grows up in the information age should have the basic skill of learning to learn, that is, the ability to access, evaluate and use rapidly changing information from various sources. Literacy skill is one of the skills that can enable individuals and those with special needs to participate actively in social life and increase their quality of life. As a result, schools today need to reconsider the needs of students and the age, and to organize learning environments in accordance with the conditions and expectations of the age. It is not always easy to protect after literacy is achieved in the society.

Keywords: Literacy, importance, education.

Copyright (C) 2022 The Author(s): This is an open-access article distributed under the terms of the Creative Commons Attribution 4.0 International License (CC BY-NC 4.0) which permits unrestricted use, distribution, and reproduction in any medium for non-commercial use provided the original author and source are credited.

\section{INTRODUCTIION}

Every society has to consist of people who show common behaviors and also engage in very different activities in order to preserve their existence. Every society has to have a system of directing new members to certain different activities and an education system, as well as a system of gaining certain common behaviors. The actions of creating and spreading this awareness, more effective learning and new qualifications to individuals in the society come from the basis of literacy. For this reason, it is important to look at a certain order in the administration and society and the views focused on this order in terms of literacy.

Successful individuals of the future will be individuals who can access information, use technology to reach information, solve problems and learn by themselves. Information societies now need individuals with lifelong learning skills.

\section{CONCEPTUAL FRAMEWORK}

Being literate after the twenty-first century requires more than just reading, writing, or basic mathematical knowledge. There is a consensus that education is one of the main developments that played a role in the birth of civilization. The existence of writing as a communication tool is a very important development. It has been ensured that historical events can be determined in a healthy way with written words, and the rapid dissemination of information about writing in a wider area has made it possible to transfer the knowledge of life from generation to generation. There is no longer any need to rely on memory to detect events. It allows individuals to validate the information themselves in writing.

According to Lankshear, through literacy, the abstract language of science has replaced the concrete language of verbal memory, and analytical thinking processes pave the way for organizing, using and comparing ideas and thoughts just like visual objects. The ability to think logically and abstractly, which revealed modern science, is associated with the development of writing and literacy. According to Kurudayığlu and Tüzel's view, literacy is explained as follows; He defines it as "being familiar with the letters used in the whole text and deciphering the code method with his own grammar while reading the texts in a printed format".

Due to the strong belief in the democratic process in the majority of Greek citizens before Christ, 
Sibel Pekkolay., Sch J Arts Humanit Soc Sci, Jan, 2022; 10(1): 6-8

school and education were compulsory for all Greek citizens, especially in Athens. Learning has a human value and has been accepted as a condition for a full human being. Learning to read can be a fun and natural process. According to Holdoway; Literacy is interpreted not as a skill element, but as a skill that occurs as a natural developmental process and is used purposefully, actively and meaningfully. There are activities such as literacy cultural knowledge or scientific technical global. The way to ensure the necessary adaptation to the present and to produce such activities is provided by literacy. Every individual who grows up in the information age should have the basic skill of learning to learn, that is, the ability to access, evaluate and use rapidly changing information from various sources. Literacy skill is one of the skills that can enable individuals and those with special needs to participate actively in social life and increase their quality of life.

While the process of creating meaning through communication within the scope of the read text is called reading, the mental action made using motor skills with a higher level and more complex planning is explained as writing skill and it is explained that literacy is related to the concepts of reading and writing. The acquisition of literacy skills, which means the spontaneous use of literacy skills for specific purposes, in different environments and situations, is an element that facilitates social life for children with normal development or special needs. In our country, many areas from health to media, from finance to digital literacy are handled in various structures in terms of the importance and functions of literacy. Increasing the interest in health literacy and healthy lifestyles and obtaining a structure that includes focused user preferences in service delivery, increasing the awareness of households and companies to save by increasing financial literacy and increasing the level of knowledge about the financial tools that guide savings, increasing participation in education in terms of digital literacy, increasing the participation in education in schools. It is aimed to strengthen literacy skills such as media, law, health and nutrition in social service centers and to find activities to increase awareness about it. Because literacy is one of the structures that have priority in terms of society. It is a means of understanding, sharing, interpreting and transferring the knowledge, skills and social norms in the society to the next generations.

The important framework of literacy starts with the individual's writing his/her name and surname, continues with the education he receives and starts to read and write and finally, it continues with his/her literacy skills in line with the needs of modern society.

In conclusion, schools today need to reconsider the needs of students and the age, and to organize learning environments in accordance with the conditions and expectations of the age. For this purpose, in a multi-channel, collaborative learning process that includes the use of technology; Learning environments are prepared where they can access information from various sources, use information for problem solving, decision making and planning, transfer information to daily life, and use technology as a means of accessing information. On the other hand, it is seen that the relationship between social development and economic growth is open to discussion. It is not always easy to protect after literacy is achieved in the society. In order for the provided literacy to be permanent and to be protected, the literacy level must exceed a certain threshold. Thus, the education should cover a long period of time to have a permanent trace. This situation, which can be permanently scarred, is determined as compulsory education in many countries and covers periods ranging from five to ten years.

Lifelong learning is to raise awareness of lifelong learning to the people in the society with the understanding of the power of knowledge, since the economic and technology-oriented changes and developments of the states have gained change in the education policies that require high-level qualified manpower.

In conclusion, it is seen that literacy is both an input and a product of this learning process. Because literacy; It is one of the most important criteria that shows the development status of societies, as well as an indicator of the success of the individual in the society, such as school success, professional success, life success. Thus, literate individuals will seek accurate and comprehensive information to make decisions in all areas of their lives, access information effectively and effectively, develop their feelings and thoughts, evaluate them critically, use them effectively and creatively, transfer them to the group they are addressing in an appropriate level and format, and communicate ethically. will behave. In addition, it is believed that literate people will contribute to the solution and progress of the problems of the society in which they live, as well as to improve themselves.

\section{REFERENCES}

- Altun, A. (2005). Emerging Technologies and New Literacy, Memoirs Publishing, Ankara.

- Asic1, M. (2009). Literacy as a Personal and Social Value, Journal of Values Education, 7 (17), 9-26.

- Avar Vayvay, N. (2020). Investigation of the Relationship Between Educational Philosophies Adopted by Preschool Teachers and Education Program Literacy Levels, Master's Thesis, Kahramanmaraş Sütçü İmam University, Social Sciences Institute, Department of Curriculum and Instruction.

- Aydin, M. (2014). Society, Culture, Education. Ankara: Gazi Bookstore. 
- Breivik, P. S. (1991). "A Signal for the need to restructure the learning process", NASSP Bulletin, 15(535), 1-7.

- Ege, P. (2005). Literacy development in children. Topbas, S. S. (Ed.), Language and concept development (140-144). Ankara: Kök Publishing.

- Gul, G. (2007). The Role of Family Participation in the Literacy Process, Ankara University Faculty of Educational Sciences, 8 (1), 17-30.

- Güneş, F. (1997). Literacy teaching and brain technology. Ankara: January Publications.

- Güneş, F. (2019). Literacy Approaches, Journal of Boundless Education and Research, 4 (3), 224-246.

- Gürdal, O. (2000). Lifelong learning activity: Information literacy. Journal of Turkish Librarianship, 14(2), 176-187.

- Holdaway, D. (1979). Fundamentals of literacy, Sydney, Australia, Ashton Scholastic.
- Kaya, E. (2020). Social Inequality and Digital Literacy: A Field Study on High School Students, Master Thesis, Konya: Selçuk University, Institute of Social Sciences.

- Kurudayığlu, M., \& Tüzel, S. (2010). 21st Century Literacy Types, Changing Text Perception and Turkish Education, TÜBAR, 283-298.

- Kurbanoğlu, S., \& Akkoyunlu, B. (2001). A Study on Gaining Information Literacy Skills to Students. Hacettepe University Faculty of Education Journal, 21, 81-88.

- Lankshear, C. (1999). Literacy studies in education: Disciplined developments in a postdisciplinary age. Published in M. Peters (Ed.), After the Disciplines. Greenwood Press.

- Strategy, T. R., \& Budget Department. (2019). Eleventh Development Plan (2019-2023), Ankara.

- Vacca, R. T., \& Vacca, J. A. (2005). Content area of reading: Literacy and learning across the curriculum. USA: Allyn and Bacon, Pearson Pub. 